Federal Reserve Bank of Minneapolis Quarterly Review Spring-Summer 1981
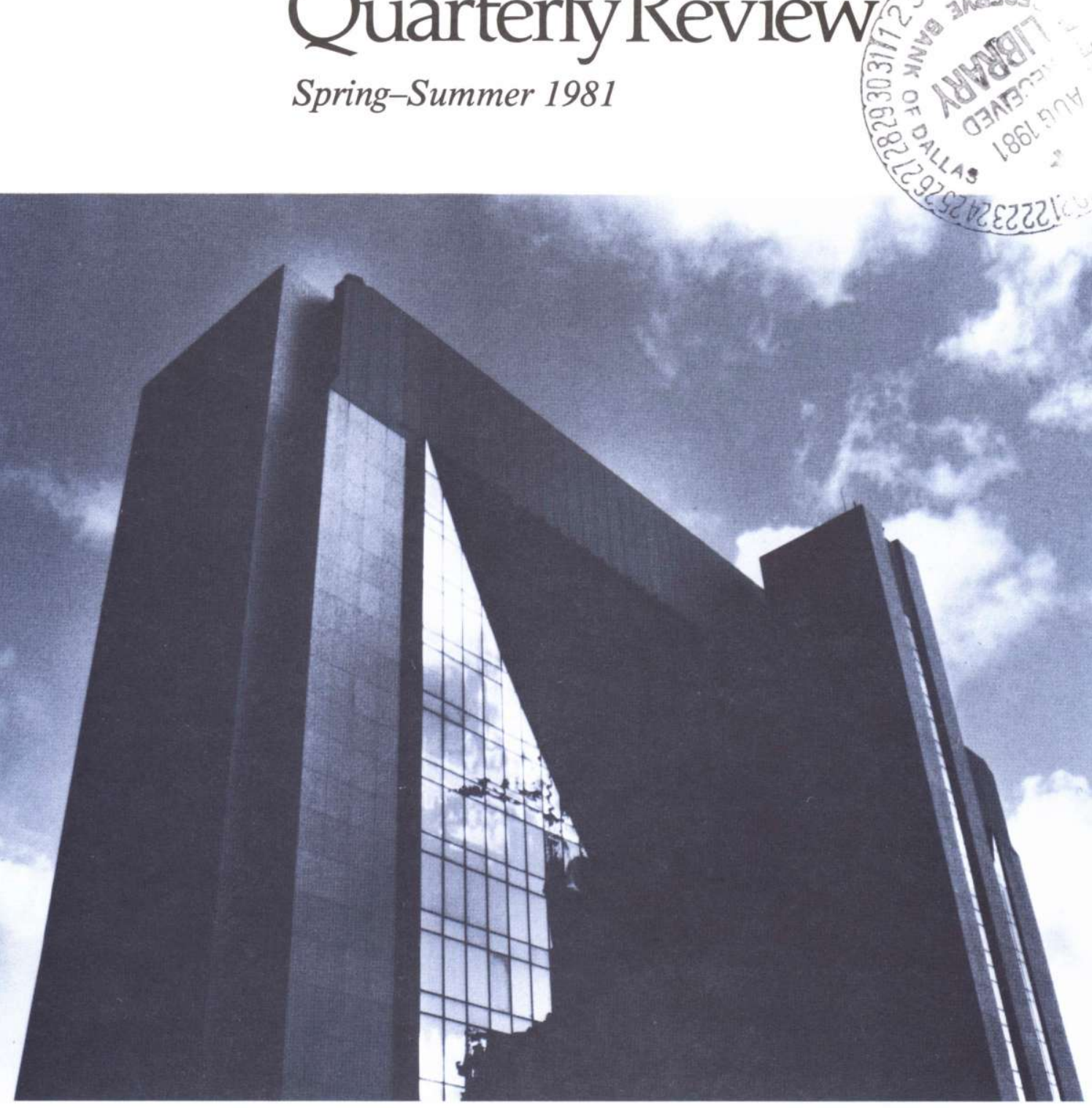
Federal Reserve Bank of Minneapolis

Quarterly Review vol. 5, No.2

This publication primarily presents economic research aimed at improving policymaking

by the Federal Reserve System and other governmental authorities.

Produced in the Research Department. Edited by Arthur J. Rolnick, Kathleen S. Rolfe, and Alan Struthers, Jr.

Graphic design and charts drawn by Phil Swenson, Graphic Services Department.

Address requests for additional copies to the Research Department,

Federal Reserve Bank, Minneapolis, Minnesota 55480.

Articles may be reprinted if the source is credited and the Research

Department is provided with copies of reprints.

The views expressed herein are those of the authors and not necessarily those of the Federal Reserve Bank of Minneapolis or the Federal Reserve System. 


\section{Deregulating Commercial Banks: The Watchword Should Be Caution}

John H. Kareken, Adviser

Research Department

Federal Reserve Bank of Minneapolis

and Professor of Economics

University of Minnesota

Deregulation is very much the fashion now, at least in the United States. That being so, there is a good chance (or glittering prospect) that over the years immediately ahead many U.S. companies will become freer to do as they want. Even our commercial banks, long tightly regulated, could become freer. We may see geographical restrictions relaxed. There has already been some relaxation of balance sheet restrictions, those that limit banks in what they can do. And, more to the point here, there may be more. Such is the present-day mood.

Perhaps relaxing geographical restrictions would be in the public interest. But that relaxing balance sheet restrictions would be is far less clear. Many, quite a few academic experts included, have urged some relaxation or, in other words, that our banks be deregulated, although not completely. (As I use the word herein, deregulation is synonomous with relaxation of balance sheet restrictions.) Whatever proponents believe, however, no one has yet made a convincing case for deregulation. In my view, regulation is required because our deposit insurance, provided by the Federal Deposit Insurance Corporation (FDIC), is improperly priced, and the effect of the FDIC's pricing policy is to make insured banks riskier than they would otherwise be. Those who would deregulate must therefore explain why, even though the FDIC's insurance is improperly priced, deregulation nevertheless makes sense.

In the United States, what any insured bank pays for its insurance depends only on the total of its eligible liabilities and the price set by the FDIC. The total of eligible liabilities is hardly an adequate measure of the risk of failure, though, and, as the Federal Deposit Insurance Act requires, there is only one price for all insured banks. That price may vary with the FDIC's insurance fund, but since insured banks are not able effectively to supervise each other, there is nothing in the FDIC's pricing policy, prescribed by the Federal Deposit Insurance Act, to discourage risk-taking.

Possibly the FDIC should be risk-rating insured banks and charging accordingly. So far as I am aware, however, no one has yet come close to a satisfactory measure of risk. And producing one would, I think, be a horrendous task. Then, too, there could be political trouble in charging banks different prices. So it may not be entirely appropriate to describe FDIC insurance as being improperly priced. Still, it is a fact that the FDIC is not at present charging insured banks according to the riskiness of their respective balance sheets. Nor is there any real prospect that it soon will be. That, as I argue later on, is why our insured banks must be regulated, probably at least as tightly as, although not necessarily in precisely the way, they currently are.

Of course, my argument may be dead wrong. Possibly I have overlooked something. But until someone shows that, policymakers must, I believe, view deregulation as a chancy undertaking.

It has often been claimed, mostly by academic experts, that we would have a better allocation of real resources if our banks were less restricted in their balance sheet choices. But that, it seems to me, is wrong. More likely than not, we would have a worse allocation. That is in effect what I argue in the first part of this essay. In the conventional view, balance sheet restrictions distort resource allocation. As applied to insured banks, though, they may not; rather, they may remove a distortion caused by the FDIC's pricing policy. And if they do, then some 
such restrictions are desirable. Or, as I suggested above, our insured banks should be regulated.

It has also been claimed that our banks, ever so much more tightly regulated than, say, the money market mutual funds, are being treated unfairly. As I argue in the second part of this essay, though, that too is wrong. The liabilities of the banks are insured by the FDIC or, as might better be said, by the federal government, which includes the Federal Reserve System, and the liabilities of the money market funds are not. Thus, it is not that like companies are being treated differently or that our banks, although more tightly regulated than some of their marketplace foes, are being treated unfairly. Regulation is, as it were, the cost of having insured liabilities.

\section{Why Regulate?}

There is a view that insuring bank liabilities and regulating banks (that is, subjecting them to balance sheet restrictions) are alternative means to a single end. Consider the following passage, taken from the report of the President's Commission on Financial Structure and Regulation, which was chaired by Reed $\mathrm{O}$. Hunt and is generally referred to, not surprisingly, as the Hunt commission:

The introduction of deposit insurance, which halted runs on banks, was by far the most important reform of the [1930s]. Although the restrictions imposed on bank operations and more stringent requirements for entry into the banking business also reduced the risk to depositors and bank stockholders, the Commission believes that these were less important and were made largely redundant by deposit insurance. (Emphasis added.) ${ }^{1}$

Why only "largely redundant" is something of a mystery. Maybe the commission had in mind that the FDIC was not charged with insuring all of the liabilities of U.S. banks. In any event, what the underlying argument was seems clear enough. Before 1934 the objective of regulation was to keep banks solvent or, in the words of the Hunt commission's predecessor, the Commission on Money and Credit, to safeguard "small depositors and the money supply." ${ }^{2}$ But with the creation of the FDIC our banks became safe for most if not all creditors. And after 1933 there was therefore no (or only slight) need to regulate them.

That last statement is, however, a non sequitur. Banks can be safe for depositors and still be risky. So it does not follow that if depositors are insured, then there is nothing to worry about. If the price of insurance is unrelated to risk, as it is for banks in the United States, and if banks are not sufficiently bound by balance sheet restrictions, then there is something to worry about: banks' assets are excessively risky and real resources are therefore misallocated.

Thus, insuring bank deposits (more generally, bank liabilities) is not a substitute for regulating banks or subjecting them to balance sheet restrictions. With the price of insurance unrelated to risk, regulation is a necessary complement to insuring deposits. When deposits are risky, depositors insist on being compensated for assuming greater risk. And by their insistence they discourage some risk-taking. When, however, deposits are risk-free, depositors do not insist on promised rates of return that vary with the riskiness of banks' balance sheets. So if the government has made depositors a solemn (and, rarer, credible) promise that whatever happens they will be paid back, then there is only the government to discourage risktaking by banks. In theory, it can do that by making banks pay fees or insurance premiums for being able to offer riskfree deposits. But it must charge banks according to the riskiness of their respective balance sheets. The only alternative is to limit risk by regulating them.

\section{How Risky Should Banks Be?}

Even if it were certain that the FDIC will keep to its current pricing policy, or that the Federal Deposit Insurance Act will be left unchanged, it would not follow that our insured banks should be very tightly regulated. Or that deregulating them would be foolish. There is the question of how risky those banks ought to be.

The obvious answer (obvious for economists) is, I believe, the right one: as risky as they would be under the laissez-faire banking policy or, to define that policy, as risky as they would be if none of their liabilities were insured by government and they were not at all regulated. And if that is true, then there is a need to regulate our insured banks, although how tightly is something else again. That need is immediate, since insuring an unregulated bank's liabilities, but at a price that is independent of risk, makes the bank riskier than it otherwise would be.

Perhaps not everyone will grant that banks should be as risky as they would be under the laissez-faire banking policy. All I can say is that to date no one has argued convincingly that the number of bankruptcies under the

\footnotetext{
'The report of the President's Commission on Financial Structure and Regulation (Washington, D.C.: U.S. Government Printing Office, 1971), p. 44.

${ }^{2}$ Money and credit: their influence on jobs, prices, and growth: the report of the Commission on Money and Credit (Englewood Cliffs, N.J.: Prentice-Hall, 1961), p. 161.
} 
laissez-faire policy is not optimal and that, until someone has, the presumption must be that it is. To presume otherwise would be to suggest that somewhere along the way Adam Smith's invisible hand became arthritic.

According to some, our own history shows that under the laissez-faire policy the banking industry is "inherently unstable" or, so to say, panic prone. Our history, however, shows no such thing. How could it? The United States has never tried the laissez-faire policy. But even if there were a convincing a priori or theoretical case for inherent instability, what would follow? Nothing, unless there were also a convincing case that bank failures have harmful thirdparty effects. That has often been claimed, but so far no rigorous and detailed argument has appeared in the literature.

On certain assumptions, there are no bank failures under the laissez-faire banking policy. If there is a private cost of going bust, a cost paid by stockholders before creditors get anything, and if creditors know what every bank portfolio will be worth whatever happens in the world, then all banks are perfectly safe-entirely free, that is, of any risk of default. That is what profit maximization implies. ${ }^{3}$ It can reasonably be objected, though, that information is not costless and that the no-failures result is therefore suspect. If information about bank balance sheets costs something, then, in general, creditors are not perfectly informed and, for banks, being safe may not yield maximum profit. Thus, even under the laissez-faire policy, there could be some failures.

That there is the possibility of some failures has an important (and, in a way, unfortunate) implication. As I have maintained, the objective in regulating insured banks is to keep them from being riskier than they would be under the laissez-faire banking policy or, equivalently, to keep bank failures down to about as many as there would be under that policy. But there is uncertainty about how many failures there would be. So it could be that at present our insured banks are too tightly regulated; it could be that for some years now the number of bank failures has been too low. Although I doubt that, I therefore cannot insist that deregulation would be foolish. But I can insist that so far no clear case for deregulation has been made. To make that case, someone must establish beyond reasonable doubt that under the laissez-faire policy banks would be riskier than they currently are or, in other words, that under the laissez-faire policy there would be more failures than there have been on average over, say, the postwar period. And much more is required than simply noting the numerous bank failures of the early 1930s. That there were many is irrelevant, for neither then nor before were our governments, federal and state, following the laissez-faire policy.

\section{Some Uninsured Bank Liabilities}

The Federal Deposit Insurance Act does not say that all creditors of insured banks are insured in full. Evidently, there are some creditors who are not. It is therefore natural to ask again whether there is any need to regulate insured banks. If some lenders are watching those banks, then why have balance sheet constraints and armies of examiners to ensure compliance with them? Why indeed?

For one thing, economic theory tells us that having some uninsured liabilities, although it may help a little, does not make balance sheet constraints unnecessary. In general, unregulated banks will be riskier when some liabilities are insured than when none are. For, as was noted above, insured creditors do not have to be promised more (or in nonbankruptcy states be paid more) as the risk of default increases. Thus, if even only some liabilities are insured, then, however well informed creditors may be, there is advantage in being less than perfectly safe.

There is another point. In the way it has gone about its business, the FDIC has made it quite reasonable for (supposedly) uninsured creditors to be unmindful of what their banks have been doing. When an insured bank has failed, or has been judged to have, the FDIC can simply pay off insured creditors. Alternatively, it can arrange for, to use the technical phrase, a purchase and assumption. That is, it can arrange for a still solvent bank to purchase the good assets of the failed bank and, in partial payment, assume all of the liabilities of that bank. The FDIC has handled most of the failures of the postwar period by purchase and assumption, so few have lost anything as a result of having made loans to insured banks. To quote Stanley Silverberg, the FDIC's Director of Research:

Because of the way failed banks have been handled in recent years, data on the insured portion of deposits do not necessarily mean much.

The majority of bank failures and all failures involving banks with deposits of $\$ 100$ million or more have been handled through purchase and assumption transactions. No depositor in a large bank failure has incurred any loss in recent decades.... In fact, no general creditor of a large bank

3ohn H. Kareken and Neil Wallace, Deposit insurance and bank regulation: a partial-equilibrium exposition, Journal of Business 51 (July 1978): 424-26. 
that failed has incurred any loss. ${ }^{4}$

It will be recalled that when the Franklin National Bank's transgressions became public knowledge, the Federal Reserve kept it open long enough for nearly all uninsured creditors to get their money out. So it is not that the FDIC has been carrying on all by itself. Nor is it just that in most instances of failure the FDIC has in effect paid off all creditors, insured and uninsured alike. It has on occasion kept banks in trouble from going under.

What the FDIC has done then, with a bit of help from the Federal Reserve, is make it very easy to believe that practically all of the liabilities of banks are insured. Of course, at some time in the future it may change its policy. Until it does, though, nominally uninsured creditors will not be as watchful as they would be if some had lost considerable sums. They will not be doing what, if truly uninsured, they might have been counted on to do.

\section{The Matter of Equity}

I have argued the need for regulating our insured commercial banks and also, although not explicitly, made a case for regulating insured state-chartered banks as tightly as those with federal charters. State-chartered banks do not pay more or less for insurance than federally chartered banks. So there is no justification for regulating them more or less tightly or, going further, for having truly independent state regulatory agencies. A multiplicity of regulatory agencies may afford banks needed protection from government. But if so, then a mistake was made decades ago, when it was decided that state-chartered banks should be eligible for FDIC insurance. To be sure, they pretty much had to be made eligible, for one of the principal motives in creating the FDIC was to save the then smaller (or unit) banks, many of which had state charters, from oblivion. Salvation, though, hardly ever comes cheap.

I have also made a case, although again not explicitly, for regulating our government-insured savings and loan associations, credit unions, and savings banks. The pricing and failed-bank policies of the Federal Savings and Loan Insurance Corporation and the National Credit Union Administration do not differ in essential ways from those of the FDIC. Not that savings and loan associations, for example, should necessarily be regulated as they have been. But if what I have argued is right, then they should be regulated.

It may even be that other government-insured depository institutions-savings and loan associations, credit unions, and savings banks - should be bound by about the same balance sheet restrictions as insured commercial banks. There is a suggestion that they should be in the justification for regulation that I have provided.

There is another disparity in regulation. Our commercial banks (and bank holding companies) are more tightly regulated than the money market mutual funds or, what may be a better contrast, the now emerging financial-service conglomerates. The question, of course, is what to do about the disparity. That has of late been much debated.

Some have maintained that because of the disparity our banks are at a serious and unfair competitive disadvantage and that either the money market funds should be more tightly regulated or the banks should be less so. The money market funds, or at least those that offer thirdparty payments services, might be made to hold cash reserves. And the banks might be allowed to pay whatever interest rates they think appropriate and issue whatever kinds of liabilities they want. If they could, then we would not see funds making money by borrowing from the public and lending to banks.

What has been quite overlooked, though, in the discussion of what to do about the disparity in regulation is that the liabilities of the money market funds are not insured by the government. The money market funds do not have an FDIC of their own. Nor has the Federal Reserve publicly committed itself to helping them out, should they get into trouble. Thus, although our banks are more tightly regulated than the money market funds, that does not mean that they are necessarily at a competitive disadvantage. The money market funds can do some things that the banks cannot. But they cannot offer government-insured liabilities. And interestingly, households and companies (among them, so-called institutional investors) would seem to know that. Casual observation indicates that they are very much aware of what money market fund balance sheets are, much more aware than of what bank balance sheets are. Nor is it accidental that funds and banks differ so in their balance sheets.

At this moment, depositors may not see much value in government insurance. Fifty years is a long time to remember anything, even a banking crisis of impressive proportions; and for much of our population that crisis is not something lived through, but only a story told by parents

${ }^{4}$ Stanley C. Silverberg, Implications of changes in the effective level of deposit insurance coverage, in Proceedings of a conference on bank structure and competition (Chicago: Federal Reserve Bank of Chicago, 1980), p. 209. 
and historians. So the possibility that with existing interest rate ceilings, banks are in fact (or have long been) at a competitive disadvantage cannot be dismissed out-ofhand. Then, too, banks may be paying too much for their insurance. That they are is not obvious, since the cost of ensuring compliance with balance sheet restrictions is more than the FDIC spends. Still, there is the possibility that the FDIC is charging too much, and that is a second reason why its insurance ought to be truly voluntary.

Simply making FDIC insurance voluntary would almost certainly not give banks the freedom that, according to bankers, they require. It is nearly beyond imagining that in making insurance voluntary, Congress and state legislatures (or regulatory agencies) would exempt uninsured banks from all or even most balance sheet restrictions. Nor apparently is near-complete freedom necessary. In the opinion of many bankers, it would seem, it will suffice to get rid of interest rate ceilings and restrictions on the maturities and denominations of bank liabilities. And, indeed, that has been promised.

It is, however, a clear implication of the existence of FDIC insurance, priced as it is, that getting rid of interest rate ceilings is not something to be done casually. Doing that would be to deregulate, for restricting banks in their borrowing is one way of limiting the FDIC's exposure. I do not say that having interest rate ceilings is a particularly good way of keeping the FDIC's exposure down, but only that if those ceilings are removed, then other balance sheet restrictions must be made more stringent. Fortunately, the reality is that a company does not have to have a bank charter to be, for all practical purposes, a bank. Undeniably, Merrill Lynch has shown that. Thus, bankers do have a genuine choice. If they feel too bound by regulation, then they can, as it were, go over to the other side. Although it is more easily threatened than done, they can give up their bank charters.

\section{Conclusion}

Virtually all of the liabilities of our banks are insured, in the first instance, by the FDIC, and the FDIC does not take risk into account in charging for its insurance. Those are facts, known to nearly all. They have been almost completely ignored, though, by those who have advocated deregulation. And that is too bad, for it means that what they have had to say adds up to precious little.

That we have the insurance arrangement we do is basic. Since we do, our insured banks must be regulated. Other government-insured depository institutions must be too.
As I remarked earlier, that is not to say that the insured banks, or any of the other government-insured depository institutions, must be regulated exactly as they are at present. I have not shown that or, indeed, that any deregulation would be foolish. But what I have done, or so I hope, is remind those interested in the regulation of banks that the obvious has been ignored and, further, that a convincing case for deregulation has yet to be made. 